\title{
REVIJA ZA ELEMENTARNO IZOBRAŽEVANJE
}

JOURNAL OF ELEMNTARY EDUCATION

Vol. 12, No. 2, pp. 139-154, Junij 2019

\section{E-LEARNING MATERIALS FOR THE SLOVENE LANGUAGE IN ELEMENTARY SCHOOLS (6 $6^{\mathrm{TH}}-9^{\mathrm{TH}}$ GRADE)}

\author{
Alenka Valh LoperT ${ }^{1} \&$ MiHaela KOLETniK ${ }^{1}$ \\ ${ }^{1}$ University of Maribor, Faculty of Arts, Slovenia \\ KORESPONDENČNI AVTOR/CORRESPONDING AUTHOR \\ alenka.valh@um.si
}

Potrjeno/Accepted 13. 3. 2019

Objavljeno/Published 28. 6. 2019

\begin{abstract}
Povzetek The theoretical part of the paper presents the project Slovensina na dlani (Slovene in the palm of your hand), which is intended for the establishment of an interactive learning environment for the Slovene language (as mother tongue) in elementary and secondary schools. In this paper we limit the research to elementary school. In the empirical section, we focus on freely available e-learning materials for the Slovene language from the $6^{\text {th }}$ to the $9^{\text {th }}$ grade of elementary school and present the results of an analysis of 10,118 tasks according to their types. The findings indicate an unbalanced representation of different types of tasks, with short answer types in the majority, the task type that is least popular among students. By introducing the most advanced linguistic technology into learning processes, we try to overcome the limitations of existing e-resources for learning the Slovene language.

E-gradivo za slovenski jezik v osnovni šoli (6. - 9. razred) $\mathrm{V}$ teoretičnem delu prispevka bo predstavljen projekt Slovenščna na dlani, ki je namenjen vzpostavitvi interaktivnega učnega okolja za učenje slovenščine kot materinščine $\mathrm{v}$ osnovnih in srednjih šolah. $\mathrm{V}$ tem prispevku se omejujemo na osnovno šolo. $\mathrm{V}$ empiričnem delu se osredotočamo na prosto dostopna e-gradiva za učenje slovenščine od 6. do 9. razreda osnovne šole in predstavljamo rezultate analize 10118 nalog glede na njihov tip. Ugotovitve kažejo na neuravnoteženo zastopanost različnih tipov nalog, pri čemer prevladujejo naloge s kratkim odgovorom, ki so med učenci najmanj priljubljene. Z uvajanjem najsodobnejših jezikovnih tehnologij $\mathrm{v}$ učne procese poskušamo premagati omejitve obstoječih e-gradiv za učenje slovenščine.
\end{abstract}

Keywords:

the Slovene language, mother tongue, elementary school, elearning resources,

Slovenšcina na dlani

Ključne besede: slovenski jezik, materni jezik, osnovna šola, eučni viri, Slovenščina na dlani

UDK/UDC

811.163.6:373.3 


\section{Introduction}

The article will explore question types in existing E-learning resources for the Slovene language as mother tongue, and will ascertain which types should be integrated-as being the most desirable, but currently under-used-into a typical textbook to maximise learning opportunities for learners. The project Slovenšcina na dlani was implemented in August 2017, and its main aim is the creation of an interactive learning environment for the Slovene language in elementary and secondary schools. The creators of the project, however, have set up the project in order to overcome the limitations of existing e-resources for the Slovene language learning, so it is no longer just a transfer of the printed workbooks into an electronic form.

The present article focuses on a review of existing, freely accessible materials for teaching/learning the Slovene language from the $6^{\text {th }}$ to the $9^{\text {th }}$ grade of elementary school and the results of an analysis of current e-learning resources according to question types. The findings show an unbalanced representation of different question types, with a dominant type that is least popular among students. In what follows, the second phase of the project, secondary school materials, will be taken into consideration, using the same criteria.

Slovene experts have carried out research (O kakovosti 2018, p. 8) on the quality of Slovene textbooks, discussed the content-didactic and professional aspects of textbooks at the primary level of elementary school within various subjects, including textbooks for the Slovene language. Four criteria of assessment have been taken into consideration:

(1) Thinking-a textbook promotes problem/critical/creative thinking.

(2) Vocabulary, language-a textbook encourages the enrichment of the vocabulary to a sufficient extent and includes appropriate professional terminology, as well as illustrating the professional concepts with an example or an illustration, i.e. with an image, a model etc.

(3) Content-the examples used in the textbook are related to everyday life, the textbook enables meaningful cross-curricular integration and deals with current scientific knowledge and topical issues.

(4) Learning, knowledge-a textbook meets the requirements of an appropriate level of student development and includes an appropriate level of complexity; it enables the inclusion of the student's pre-knowledge and a pre-knowledge check; it increases the difficulty for the progress of the learners; it encourages active forms of learning, 
learning by research and collaborative learning; it allows learners to reflect on their own learning, and enables self-evaluation of knowledge.

According to teachers' responses, the researchers stated (O kakovosti 2018, p. 9), on the one hand, that a high percentage of textbooks for the Slovene language at the primary level of elementary school do the following:

(1) stimulate problem solving $(79 \%)$, critical $(78 \%)$ and creative thinking $(82 \%)$;

(2) promote the enrichment of vocabulary $(89 \%)$, give professional examples with illustrations $(85 \%)$;

(3) use examples from everyday life (85\%), allow cross-curricular integration (82\%); $(89 \%)$, allow the inclusion of student's pre-knowledge $(82 \%)$, allow students to check their pre-knowledge (68\%), and enable student progression (70\%).

On the other hand, in the opinion of teachers, the following characteristics of textbooks are represented in a lower percentage:

(1) textbooks promote active forms of learning (57\%),

(2) enable self-assessment of knowledge (50\%);

(3) allow students to reflect on daily learning (only 6\%); and

(4) discuss contemporary scientific findings (52\%).

The findings of the research coincide with the main guidelines for the preparation of new learning materials for the Slovene language, and we will strive to achieve the highest possible level of consideration of these goals.

\section{On the Project Slovenščina na dlani}

The project Slovenšščina na dlani (Gradivo za izobraževanje 2017; Internet source: http:/ / projekt.slo-na-dlani.si/sl/) is co-financed by the Ministry of Culture of the Republic of Slovenia and by the European Union, i.e. the European Social Fund. It is carried out at the University of Maribor, including three faculties: the Faculty of Arts, the Faculty of Education and the Faculty of Electrical Engineering, Computer Science and Informatics. It will last four years, until the end of September 2021.

During the project period, fourteen educational institutions (primary and secondary schools) from all over Slovenia will participate in order to improve the responsiveness of the formal education system and increase its attractiveness. 
The purpose of the project is to create an innovative, interactive learning e-resource by introducing the most advanced linguistic technology into the learning processes, on the one hand. On the other hand, we seek to offer students an e-environment that is highly automated. It will provide (for certain tasks) an almost unlimited number of individualised exercises and adapt automatically to the needs of each individual user, while being interactive in the sense of automatically providing information to the user on his/her achievement and performance and automatically directing him/her among tasks, using the advantage of gaming elements from the computer environment to motivate students.

The target group comprises students from the $6^{\text {th }}$ to the $9^{\text {th }}$ grades of elementary school and secondary school students, who can produce longer texts, but with deficits in language expression and understanding, especially in the case of nonliterary texts. It is precisely these deficits that are targeted in our new learning eresource, Slovenšcina na dlani. The learning e-environment will be freely accessible and adapted for use on tablets and smartphones. It will be available to anyone, even without registration, but registration is desirable for use in schools, so that students can take full advantage of all the potential of e-environment adaptation to each individual user.

The e-exercises will be divided into five content sets: (1) orthography (use of commas, capital letters, words written together and apart, etc.), (2) grammar (use of prepositions, conjunctions, pronouns, etc., difficulties in conjugation, declension and comparison), (3) idioms, proverbs, (4) texts (reading and summarizing), and (5) explanation of linguistic topics.

\section{Theoretical insight}

Common to all the free e-learning materials for Slovenian language in elementary school (those reviewed for this paper) from the $6^{\text {th }}$ to the $9^{\text {th }}$ grades is that they are designed to provide students and teachers with many (diversified) question types. They differ from each other according to how they are compiled, according to the level of student activity in solving tasks, according to predicted response, and according to demand, namely the taxonomic level. We point out-in our area, the best known-three different classifications of types of tasks that differ in the way they are sorted. 
As early as 1965, the Slovenian psychologists Ivan Toličič and Leon Zorman had classified and described the question types in their Testi znanja in njibova uporaba $v$ praksi (Tests of Knowledge and Their Application in Practice, 1965). They divided the question types into two groups with several subtypes, using as criteria for the division the composition of the question types and the manner in which students answer them. The first group lists question types for which the answer needs to be written, that is, question types requiring the reproduction of learning material (complement question types and the short answer). In the second group, there are question types in which the answer should be selected (optional type/with subtypes), the linking and editing type, and the alternative type (with subtypes) (Toličič, Zorman 1965, pp. 26-57). They also mention question types with free answers that require a written response but do not classify these in any group. In 1968 (pp. 81-84), Zorman also wrote about interpretational question types, which are more demanding and complex on the level of content and form in comparison to other question types. These are suitable for identifying complex educational components (e.g. knowledge of cause-effect relationships or the ability to develop hypotheses), but among pupils with less reading ability, these are very unpopular, as they usually contain a great deal of text.

In her paper Pisno preverjanje in ocenjevanje pri pouku slovenskega jezika v tretjem triletju osnovne sole (Written examination and evaluation in Slovene language classes in the third trimester of elementary school, 2008), Slavist Tamara Vomer divides the question types into two groups:

In the first group, they are classified according to the level of understanding of the text-i.e. factual question types, in which the individual is expected to copy the answers literally from the given text; concluding question types, which require the individual to conclude on an answer that is not literally given in the text, and the critical/creative/applicable question types, requiring a certain pre-knowledge. In the second group, she classifies question types according to the learner's activityquestion types of a closed or objective type, requiring the individual to choose an answer from the multiple answers given or specify a specific answer; question types of a semi-open or partially objective type, which the individual needs to answer or solve independently, with the type of answer being specified by the instructions, or question types that are composed of several different question types or subquestions that are not necessarily interdependent: question types of an open or subjective type (all with several subtypes), which are characterized by an individual showing his/her own ideas and creativity or giving his/her opinion (Vomer 2008, pp. 34, 35). 
In 2002, psychologists Barica Marentič Požarnik and Cirila Peklaj divided assignments into two groups in the Preverjanje in ocenjevanje za uspešnejsi studij (Verification and Assessment for More Successful Study). The first ones are essay assignments, i.e. question types in which an individual responds freely, with a longer answer (a discussion essay, an essay with an element of role-play), and the second group comprises objective question types, which are further subdivided into opentype tasks (question types with short answers and complement question types) and closed-type questions (question types of the optional and alternative type, and the question type of connecting and editing) (Marentič Požarnik, Peklaj 2002, pp. 73, $74,87)$.

In her Master's thesis (2017), the Slavist Maja Hadner concludes that, despite these classifications, some question types cannot be subsumed under the given types. Therefore, she upgraded existing classifications and question types according to the activity they require from the individual. The new, extended classification thus encompasses 21 question types, some types from existing classifications being also renamed.

\section{Existing E-Learning Resources for Learning the Slovene Language in Elementary School}

The following section presents materials for learning the Slovene language in elementary schools from the $6^{\text {th }}$ to the $9^{\text {th }}$ grades-freely accessible on the Internet (Internet source: http://projekt.slo-na-dlani.si/sl/). The study took place in 2017, from June until December. We were interested in question types and exercises, considering non-literary texts and covering the following topics: the Slovene language in general, the historical development of the Slovene language and its contemporary situation as well as its social and functional varieties, phonetics, orthography, lexicology, word classes, sentence elements and complex sentences etc.

The analysis includes the following textbooks, workbooks and additional interactive materials:

1: Gradim slovenski jezik 6 - dodatno gradivo k učbeniku (Additional material to the Textbook, $6^{\text {th }}$ grade);

2: Gradim slovenski jerik 6 - dodatno gradivo k delovnemu zvezku (Additional material to the Workbook; $6^{\text {th }}$ grade);

3: Gradim slovenski jezile 6 - dodatno gradivo k samostojnemu delovnemu zvezku (Additional material to the autonomous Workbook; $6^{\text {th }}$ grade); 
4: Slovenšcina v oblaku: interaktivno gradivo za slovenščino v 6. razredu osnovne šole (Interactive material; $6^{\text {th }}$ grade);

5: Od glasov do knjižnih svetov 6 ( $6^{\text {th }}$ grade);

6: Slovenšina, Vaje za 6.-9. razred (Exercises: $6^{\text {th }}-9^{\text {th }}$ grade);

7: Devetka.net - Zbirka spletnih nalog (Collection of interactive tasks);

8: E-uchbeniki SIO.si: 8. razred ( $8^{\text {th }}$ grade);

9: Projekt slovenšcina za 8. razred - Neumetnostna besedila (Part: Non-literary texts: $8^{\text {th }}$ grade);

10: E-uchbeniki SIO.si: 9. razred (9 $9^{\text {th }}$ grade).

\section{Methodology}

E-resources were reviewed and analysed according to the question types formulated and completed by Hadner (2017, pp. 25-33; terminology and typology of question types were also adjusted according to Internet source: https://docs.moodle.org/34/en/Category:Questions) that occur in all materials, i.e. textbooks, workbooks and additional interactive materials. Individual question types were checked and counted, and then percentages of all question types in the analysed materials were calculated. Within the analysis, 21 different question types were examined: 1 Fill in the blank questions-this question type requires the student to complete or finish a statement by writing in the missing words, phrases or short clause. 2 Short answer questions-this question type requires only a brief/short response, i.e. with a word or phrase; no reply with a sentence is necessary. 3 Multiple choice questions (one correct answer)-this question type requires only one correct answer from the answers offered. 4 Multiple answer questions (two correct answers)-this question type requires two correct answers from the answers offered. 5 Multiple answer questions (answers where several are correct-this question type requires several choices, i.e. at least three answers from the answers offered. 6 Multiple choice questions with varying degrees of correctness-the individual is expected choose the most appropriate/correct from the offered answers. 7 Multiple choice questions with an incorrect answer-the individual is expected to identify the wrong answer from the answers offered. 8 Multiple choice questions with the best answer-this question type offers several correct answers, the best of which should be chosen. This question type is very similar to the optional type of question with varying degrees of correctness. 9 Matching questions-this question type requires connecting individual elements to meaningful relationships. 10 Editing questions-this question type requires organization of given elements by a certain criterion. 11 Alternative questions-this question type requires an answer or a definition with one of the two responses offered (for example, true/false, yes/no). 12 Alternative questions with argumentationthis question type is composed of an alternative question type, and in addition, it 
requires a justification for the selected answer. 13 Open questions-this question type requires a longer answer formed in the student's own words. 14 Oral responses-this question type requires a response that does not need to be written. 15 Gap-fillingthis question type requires a specific element to be inserted into the word or text (for example, missing letters or punctuation marks). 16 Mark correct answer (of the multiple-choice answers)-this question type requires that something be marked, underlined, circled or coloured in. 17 Error Correction-this question type requires that the incorrectly written word, text or incorrectly written punctuation be corrected. 18 Ordering questions-this question type requires that the given elements be classified or distributed according to a given criterion. 19 Reading-this question type requires that the word or text be read carefully. 20 A type including in-class activities-this question type requires classroom activities among students. $21 \mathrm{~A}$ type involving other resources-this question type provides for the use of other materials and usually relates to a particular topic or substance and seeks to bring it closer to a student's real-life situation. (Hadner 2017, pp. 25-33).

The total number of question types analysed within the e-resources was 10.118 . Thus, we sought to obtain data on the representation of individual question types in e-materials and compare the results with those question types that turned out to be the most common in Slovene language learning.

Question Type Analysis of Exercises in Existing E-Learning Resources for Learning the Slovene language

The tables present a set of tasks that represent at least $70.0 \%$ of all tasks in individual e-resources. Tasks representing less than $4.0 \%$ of tasks are not representative and therefore not included in the tables.

Table 1: Gradim slovenski jezik 6 (additional material to the Textbook; $6^{\text {th }}$ grade).

\begin{tabular}{lcc}
\hline Question types & Number of tasks & Percentages (\%) \\
\hline Short answer questions & 36 & $46.8 \%$ \\
\hline Fill-in-the-blank questions & 12 & $15.6 \%$ \\
\hline Multiple choice questions & 10 & $10.4 \%$ \\
\hline Gap-filling & 5 & $6.5 \%$ \\
\hline Alternative questions & 4 & $5.2 \%$ \\
\hline
\end{tabular}

Total: 77 tasks. The most common question types appear in $84.5 \%$ of all tasks, while other question types appear in $3.9 \%$ or less. 
Table 2: Gradim slovenski jezik 6 (additional material to the Workbook; $6^{\text {th }}$ grade).

\begin{tabular}{lcc}
\hline Question types & Number of tasks & Percentages (\%) \\
\hline Short answer questions & 97 & $60.3 \%$ \\
\hline Fill-in-the-blank questions & 13 & $8.1 \%$ \\
\hline Open questions & 10 & $6.6 \%$ \\
\hline Multiple choice questions & 8 & $5.0 \%$ \\
\hline
\end{tabular}

Total: 160 tasks. The most common question types appear in $80.0 \%$ of all tasks, while other question types appear in $3.8 \%$ or less.

Table 3: Gradim slovenski jezik 6 (additional material to autonomous Workbook; $\mathbf{6}^{\text {th }}$ grade).

\begin{tabular}{lcc}
\hline Question types & Number of tasks & Percentages (\%) \\
\hline Short answer questions & 111 & $59.0 \%$ \\
\hline Alternative questions & 20 & $10.6 \%$ \\
\hline Multiple choice questions & 14 & $7.5 \%$ \\
\hline Open questions & 13 & $6.9 \%$ \\
\hline
\end{tabular}

Total: 188 tasks. The most common question types appear in $84.0 \%$ of all tasks, while other question types appear in $3.2 \%$ or less.

Table 4: Slovenščina v oblaku: (Interactive material; $6^{\text {th }}$ grade).

\begin{tabular}{lcc}
\hline Question types & Number of tasks & Percentages (\%) \\
\hline Multiple choice questions & 10 & $14.7 \%$ \\
\hline Mark correct answer & 9 & $13.2 \%$ \\
\hline Open questions & 8 & $11.8 \%$ \\
\hline Short answer questions & 7 & $10.3 \%$ \\
\hline Reading & 5 & $7.4 \%$ \\
\hline Ordering questions & 5 & $7.4 \%$ \\
\hline Fill-in-the-blank questions & 4 & $5.9 \%$ \\
\hline Multiple answer questions (several correct answers) & 4 & $5.9 \%$ \\
\hline
\end{tabular}

Total: 68 tasks. The most common question types appear in $75.9 \%$ of all tasks, while other question types appear in $4.4 \%$ or less.

Table 5: Od glasov do knjižnih svetov 6.

\begin{tabular}{lcc}
\hline Question types & Number of tasks & Percentages (\%) \\
\hline Short answer questions & 27 & $44.3 \%$ \\
\hline An oral response & 21 & $34.4 \%$ \\
\hline Alternative questions & 4 & $6.6 \%$ \\
\hline Fill-in-the-blank questions & 3 & $4.9 \%$ \\
\hline
\end{tabular}


Total: 61 tasks. The most common question types appear in $90.2 \%$ of all tasks, while other question types appear in $3.3 \%$ or less.

Table 6: Slovenščina, Vaje za 6.-9. razred (Exercises, $6^{\text {th }}-9^{\text {th }}$ grade).

\begin{tabular}{lcc}
\hline Question types & Number of tasks & Percentages (\%) \\
\hline Short answer questions & 567 & $36.2 \%$ \\
\hline A classroom activity-listening & 398 & $25.4 \%$ \\
\hline Alternative questions & 344 & $22.0 \%$ \\
\hline Multiple choice questions & 130 & $8.3 \%$ \\
\hline
\end{tabular}

Total: 1566 tasks. The most common question types appear in 91.9\% of all tasks, while other question types appear in $2.0 \%$ or less.

Table 7: Devetka.net (Collection of interactive tasks).

\begin{tabular}{lcc}
\hline Question types & Number of tasks & Percentages (\%) \\
\hline Multiple choice questions & 1003 & $35.7 \%$ \\
\hline Short answer questions & 564 & $20.1 \%$ \\
\hline Alternative questions & 404 & $14.4 \%$ \\
\hline Fill-in-the-blank questions & 196 & $7.0 \%$ \\
\hline Matching questions & 162 & $5.8 \%$ \\
\hline
\end{tabular}

Total: 2807 tasks. The most common question types appear in $83.0 \%$ of all tasks, while other question types appear in $3.1 \%$ or less.

Table 8: E-učbeniki SIO.si: 8. razred (8 $8^{\text {th }}$ grade).

\begin{tabular}{lcc}
\hline Question types & Number of tasks & Percentages (\%) \\
\hline Short answer questions & 600 & $31.3 \%$ \\
\hline Multiple choice questions & 290 & $15.1 \%$ \\
\hline Alternative questions & 196 & $10.2 \%$ \\
\hline Mark correct answer & 141 & $7.4 \%$ \\
\hline Reading & 123 & $6.4 \%$ \\
\hline Open questions & 104 & $5.4 \%$ \\
\hline Fill-in-the-blank questions & 89 & $4.6 \%$ \\
\hline
\end{tabular}

Total: 1919 tasks. The most common question types appear in $80.4 \%$ of all tasks, while other question types appear in $3.1 \%$ or less. 
Table 9: Projekt slovenščina za 8. razred (Part: Non-literary texts; (8 $8^{\text {th }}$ grade)).

\begin{tabular}{lcc}
\hline Question types & Number of tasks & Percentages (\%) \\
\hline Short answer questions & 239 & $31.9 \%$ \\
\hline Open questions & 84 & $11.2 \%$ \\
\hline Reading & 77 & $10.3 \%$ \\
\hline Alternative questions & 76 & $10.2 \%$ \\
\hline A type involving other resources & 58 & $7.7 \%$ \\
\hline Multiple choice questions & 49 & $6.5 \%$ \\
\hline Alternative questions with argumentation & 32 & $4.3 \%$ \\
\hline
\end{tabular}

Total: 749 tasks. The most common question types appear in $82.1 \%$ of all tasks, while other question types appear in $3.5 \%$ or less.

Table 10: E-učbeniki SIO.si: 9. razred (9 ${ }^{\text {th }}$ grade).

\begin{tabular}{lcc}
\hline Question types & Number of tasks & Percentages (\%) \\
\hline Short answer questions & 860 & $34.1 \%$ \\
\hline Multiple choice questions & 269 & $10.7 \%$ \\
\hline Reading & 243 & $9.6 \%$ \\
\hline Mark correct answer & 232 & $9.2 \%$ \\
\hline Alternative questions & 212 & $8.4 \%$ \\
\hline Fill-in-the-blank questions & 142 & $5.6 \%$ \\
\hline Open questions & 138 & $5.5 \%$ \\
\hline
\end{tabular}

Total: 2523 tasks. The most common question types appear in $83.1 \%$ of all tasks, while other question types appear in $3.0 \%$ or less.

\section{Interpretation of Question Type Analysis}

It can be noted that simpler question types are repeated very often, while those that are more demanding, and require more complicated mental processes, are rare. Simpler question types are-unquestionably-necessary for accustoming students to thinking, but too frequent usage of these types does not stimulate in-depth thinking and leads to a decline in motivation to answer this type of question. During the process of analysis, particularly while determining the question types, we discovered a gap in the classification of question types, which we want-as much as possibleto fill with expanded question types. 
The review covered ten sets of e-resources, and 10.118 tasks were analysed:

(1) in the additional material (77 tasks) to the textbook Gradim slovenski jerik 6 the Short answer questions type is presented in $46.8 \%$ of tasks (36 tasks);

(2) in the additional material (160 tasks) to the workbook for the same text-book the Short answer question type prevails, with $60.3 \%$ of tasks ( 97 tasks);

(3) similarly, in the additional material (188 tasks) to the autonomous workbook for the same text-book, i.e. $59.0 \%$ (111 tasks);

(4) in the interactive material (68 tasks) for the text-book Slovensicina v oblaku for $6^{\text {th }}$ grade, Multiple choice questions amounted to $14.7 \%$ (10 tasks);

(5) in the text-book Od glasov do knjižnih svetov 6 (61 tasks), the Short answer question type was present in $44.3 \%$ (27 tasks);

(6) among the exercises for the text-book Slovenšcina (1566 tasks), the Short answer question type occupies $36.2 \%$ (567 tasks);

(7) the collection of interactive tasks (2807 tasks) accompanying the text-book Devetka.net includes $35.7 \%$ (1003) of the Multiple-choice question type;

(8) in the e-text-book (1919 tasks) E-ucbeniki SIO.si for the $8^{\text {th }}$ grade, 31.3\% of tasks (600 tasks) comprise the Short answer question type;

(9) in the Non-literary texts section (749 tasks) of the text-book Projekt slovenšina for $8^{\text {th }}$ grade, the Short answer question type prevails again at $31.9 \%$ (239), as well as in

(10) the e-text-book E-ucbeniki SIO.si for the $9^{\text {th }}$ grade, in $34.1 \%$ (860 tasks).

The results of the e-resources analysis reveal a shortage of the following question types: Gap-filling, Mark correct answer of the multiple-choice answers, Error Correction, Ordering questions, Alternative questions with argumentation, Editing questions, Multiple answer questions (two correct answers), Multiple answer questions (several correct answers), and Multiple choice questions with an incorrect answer. Since all these are question types that are more than suitable for e-environments, and they also enable the realization and achievement of higher taxonomic levels (use, analysis and synthesis), both the results of the analysis and the teachers' perceptions will help us to design appropriate e-resources within the framework of the project Slovenšsina na dlani.

Bernik (2011, p. 209) emphasizes, according to all the analyses carried on Slovene and foreign textbooks, in his case, for history, that $/ / . . /$ an ideal textbook cannot be made, because students have different styles of learning, and teachers have different teaching methods, so they should have different methodologically designed textbooks /.../". This is undoubtedly true for textbooks of the Slovene language as well. That is why, when composing e-materials and tasks, we will-as far 
as possible-take into account different types of perception, which is divided into five senses: visual perception, auditory (hearing) perception, kinaesthetic (movement, touch) perception, olfactory (smell) perception and gustatory (taste) perception (known as the VAKOG model). Depending on the different types, we could also suggest words (verbs for instance), used in speech patterns within the instructions, while remaining fully aware of the different effect of a given message on different groups of recipients.

\section{Conclusion}

The results show that, in the majority of e-resources, the type Short answer questions is most often represented, i.e. in $30.72 \%$ of cases (3108 tasks; in individual sources 10.3\%-60.3\%), followed by Multiple choice questions in $35.7 \%$ (1783 tasks; in individual sources $5.0 \%-35.7 \%)$ and Alternative questions in $10.52 \%(1064$ tasks; in individual sources $5.2 \%-22.0 \%$ ).

In extreme contrast to the most frequent question type (Short answer questions) present in e-resources, student answers to the questionnaire about their most/least liked question types revealed that the Short answer question type is the least popular among the elementary school population (Internet source: http://projekt.slo-nadlani.si/sl/). Considering the typology of questions comprises 21 different types, it is reasonable to follow the guidelines in the preparation of e-resources in the future, which will focus on a more balanced representation of all question types.

Some very good suggestions about question types for textbook writing have been offered by experts in the analysis of history textbooks (Bernik 2011, pp. 208-9), some of which could be used in preparing the Slovenian language learning material. Let us support them with concrete proposals related to the Slovenian language: content in the form of comics (exercises for interjections), instructions for project work (mini projects: search for linguistic-spelling/morphological-mistakes in online editions of newspapers, in e-mails, advertisements etc.), work with pictorial materials (to write down all the nouns in the picture, adjectives used with-selected-nouns, verbsactivities of people/animals in the picture etc.), blank maps (map of Slovenia-to enter multi-word geographical names with respect to capital letters etc,), a glossary of terms (a glossary of unknown/new words that can be supplemented by students themselves), social games (dominoes for word-formation, phraseology etc.), Internet addresses (search for language manuals, language counselling etc.). 


\section{References}

Bernik, V. (2011). Metodološka struktura izbranih slovenskih in tujih osnovnošolskih učbenikov zgodovine. In: D. Trškan (Ed.), Trojarjev zbornik. pp. 183-210. Ljubljana: Znanstvena založba Filozofske fakultete (Historia: znanstvena zbirka Oddelka za zgodovino Filozofske fakultete v Ljubljani; 19). Retrieved from https://hdl.handle.net/11686/file17922 (Accessed 10 $0^{\text {th }}$ February 2019.)

Hadner, M. (2017): Pregled, primerjava in analiza delovnih quezkov za pouk slovenskega jezika v srednjih šolah. Master's thesis. Maribor: Filozofska fakulteta, Oddelek za slovanske jezike in književnosti.

Marentič Požarnik, B., Peklaj, C. (2002): Preverjanje in ocenjevanje za uspešnejši študij. Ljubljana: Center za pedagoško izobraževanje Filozofske fakultete.

Koletnik, M., Valh Lopert, A. (2018): Tipologija nalog v aktualnih e-okoljih za slovenščino v OŠ. In: N. Ulčnik (Ed.), Slovenščna na dlani 1. Zbornik. [E-source]. Maribor: Univerzitetna založba Univerze. Retrieved from http://press.um.si/index.php/ump/catalog/book/341 (Accessed 10 ${ }^{\text {th }}$ February 2019.) pp. 55-59.

O kakovosti slovenskih učbenikov. Mnenja učiteljev. Prvo poročilo. (2018). (Za kakovost slovenskih učbenikov - KaUč). Retrieved from http://kauc.splet.arnes.si/files/2018/11/O_kakovosti_slovenskih_ucbenikov_mnenja_uciteljev_2018.pdf (Accessed 10 $0^{\text {th }}$ February 2019.)

Pulko, S., Zemljak Jontes, M. (2013): E-izobraževanje kot kombinirano izobraževanje pri pouku slovenšine $=$ E-learning as blended learning in the teaching of Slovenian. In: M. Orel (Ed.), Sodobni pristopi poučevanja prihajajočih generacij [zbornik referatov] = Modern approaches to teaching the coming generation [conference proceedings]. 743-755. Polhov Gradec: Eduvision. Retrieved from http://eduvision.si/Content/Docs/Zbornik\%20prispevkov\%20EDUvision\%202013_splet.pdf.

(Accessed 10th February 2019.)

Slovenšcina na dlani. Analiza trenutno aktualnih e-okolij za poućevanje jeqikov (primarno e-okolij za slovenščino) (vsebinsko poročilo junij 2017-december 2017). Pulko, S., Zemljak Jontes, S., Koletnik, M., Šek Mertük, P., Valh Lopert, A. Retrieved from http://projekt.slo-nadlani.si/sl/ (Accessed 10 th Sept. 2018)

Slovenšcina na dlani 1 [E-source]. Zbornik, 2018. (Ed.) Ulčnik, N. Maribor: Univerzitetna založba Univerze. Retrieved from http://press.um.si/index.php/ump/catalog/book/341 (Accessed $10^{\text {th }}$ February 2019.)

Toličič, I., Zorman, L. (1965): Testi znanja in njihova uporaba v praksi. Ljubljana: Zveza delavskih univerz Slovenije.

Valh Lopert, A. (2017): Lektoriranje kot učinkovita metoda učenja maternega jezika (za študente nesloveniste). In: M. Jesenšek (Ed.), Med didaktiko slovenskega jezilea in poezijo: ob 80-letnici Jožeta Lipnika $=$ When Slovene language didactics meets poetry: Jože Lipnik's 80 th anniversary. pp. 76-93. Maribor: Univerzitetna založba.

Verdonik, D., Krajnc Ivič, M., Ulčnik, N. (2017): Gradivo za izobraževanje učiteljï in učiteljev slovenščine v okviru projekta Slovenš́ina na dlani. Maribor: [s. n.]

Vomer, T. (2008): Pisno preverjanje in ocenjevanje pri pouku slovenskega jezika v tretjem triletju osnovne šole. Preverjanje in ocenjevanje: specializirana strokovna pedagoška revija, 5(2/3), pp. 11-38.

Zorman, L. (1968): Preverjanje in ocenjevanje ter opazovanje učencev v šoli. Ljubljana: DZS.

\section{Internet sources}

Projekt slovenščina za 8. razred OS ( $8^{\text {th }}$ grade):

E-gradiva, slovenščina, Projekt slovenščina za 8. razred OŠ: http://www.ssers.mb.edus.si/gradiva/w3/slo8/000_mapa/index.html Neumetnostna besedila. 
Slovenšcina v oblaku ( $6^{\text {th }}$ grade):

Slovenščina v oblaku 6: http://www.devetletka.net/gradiva/slovenscina/6; Dodatna gradiva: https://mauthor.rokus.com/svo6/demo/.

E-učbeniki SIO.si:

$8^{\text {th }}$ grade: http://eucbeniki.sio.si/slo8/index.html;

$9^{\text {th }}$ grade: http://eucbeniki.sio.si/slo9/index.html.

Gradim slovenski jezile 6: Gradim slovenski jezik 6 (6 ${ }^{\text {th }}$ grade): http://www.devetletka.net/index.ph$\mathrm{p} ? \mathrm{r}=$ downloadMaterial\&id $=2421 \&$ file $=1$

Od glasov do knji:̌nih svetov 6 (6 $6^{\text {th }}$ grade): http://www.devetletka.net/gradiva/slovenscina/6

Slovenšina (vaje 6.-9. rąred) (6 $6^{\text {th }} 9^{\text {th }}$ grade): http://www2.arnes.si/ osljik6/slovenscina_ps/slovenscina_6_9r.htm.

Zbirka spletnih nalog Devetka.net: http://devetka.net/index.php?r=1\&p=36\&t=794\&n=1\&sid=fe13-8b19ba11d098aaf4f4ddade8dd9a

http://projekt.slo-na-dlani.si/sl/

https://docs.moodle.org/34/en/Category:Questions

\section{Authors}

\section{Alenka Valh Lopert, PhD}

Associate professor, University of Maribor, Faculty of Arts, Koroška cesta 160, 2000 Maribor, Slovenia, e-mail: alenka.valh@um.si

Izredna profesorica, Univerza v Mariboru, Filozofska fakulteta, Koroška cesta 160, 2000 Maribor, e-pošta: alenka.valh@um.si

\section{Mihaela Koletnik, PhD}

Full professor, University of Maribor, Faculty of Arts, Koroška cesta 160, 2000 Maribor, Slovenia, e-mail: mihaela.koletnik@um.si

Redna profesorica, Univerza v Mariboru, Filozofska fakulteta, Koroška cesta 160, 2000 Maribor, e-pošta: mihaela.koletnik@um.si 